Egyptian Journal of Aquatic Biology \& Fisheries

Zoology Department, Faculty of Science,

Ain Shams University, Cairo, Egypt.

ISSN $1110-6131$

Vol. 25(3): 63 - 76 (2021)

www.ejabf.journals.ekb.eg

\title{
Effect of Nigella sativa enriched diet on biochemical variables and antioxidant damage caused by silver nanoparticles toxicity in the African catfish, Clarias gariepinus
}

\author{
Nermen G. Andrawes ${ }^{1}$, Afaf A. Abo Nour ${ }^{1}$, Adel A.M. Shaheen ${ }^{2}$, Heba S. Hamed ${ }^{\mathbf{1}^{*}}$ \\ 1-Department of Zoology, Faculty of women for Arts, Science \& Education, Ain Sham \\ University, Cairo 11757, Egypt. \\ 2- Department of Aquatic animals diseases and Management، Faculty of Veterinary Medicine, \\ Banha University, Banha, Egypt. \\ *Corresponding Author:hebasalah84@women.asu.edu.eg
}

\begin{abstract}
ARTICLE INFO
Article History:

Received: Nov. 25, 2020

Accepted: May. 24, 2021

Online: May 26, 2021
\end{abstract}

Keywords:

Silver nanoparticles,

Oxidative stress,

Catfish,

Nigella sativa,

Behavior,

Biochemistry,

Histopathology.

\section{ABSTRACT}

The present study aimed to investigate the effect of silver nanoparticles (AgNPs) $(50 \mathrm{mg} / \mathrm{L})$ on the behavioral changes, biochemical alterations, oxidative stress and the histopathological changes in liver tissues of African catfish, clarias gariepinus. In addition to the potential role of Nigella sativa $(N S)$ in ameliorating these effects. Fish were divided into four groups: group 1 was control fed on basal diet, group 2 was fed on $3 \%(N S)$ of basal diet, group 3 was exposed to $50 \mathrm{mg} / \mathrm{L} \mathrm{AgNPs}$, and group 4 was exposed to $50 \mathrm{mg} / \mathrm{L}$ AgNPs and fed on $3 \%(N S)$ for 30 days. Results revealed that catfish in group (3) exposed to AgNPs exhibited changes in skin pigmentation and abnormal behavior in swim. A significant elevation $(\mathrm{P}<0.05)$ in levels of alkaline phosphatase (ALP), aspartate aminotransferase (AST), and alanine aminotransferase (ALT) of catfish exposed to AgNPs compared to the control fish. Furthermore, marked increase of hepatic lipid peroxidation (LPO), catalase (CAT), total antioxidant (TAC), glutathione (GSH), and superoxide dismutase (SOD) levels were recorded in group (3). Alternatively, feding exposed catfish to AgNPs on 3\% (NS) for 30 days, decreased the levels of ALP, AST, and ALT, improved the oxidative damage in liver tissues, and attenuated the histological changes in hepatic tissues of C. gariepinus (group 4). Hence, this study suggested that (NS) has hepatoprotective and antioxidant effects in African catfish against AgNPs toxicity.

\section{INTRODUCTION}

Nanoparticles (NP) have a wide range of chemistry material science. Silver is considered a worthy metal. Ag-NPs have harmful effects on the aquatic environment (Blaser et al., 2008; wijnoven et al., 2009; Fabrega et al., 2011). Some researchers used silver for aquatic toxicity testing (Zhou et al., 2005; Yue et al., 2015; Abaragoei et al., 
2016). Exposure to AgNPs caused change in the biochemical and oxidative stress markers (Arora et al., 2009).

Nigella sativa $(N S)$ or black cumin used for food additive (Ijaz et al., 2017; Shahid et al., 2017) used for treating biochemical and oxidative stress- related toxicity and prevent oxidative damage (Adam et al., 2016; Amin and Hosseinzadeh,2016 ; Mohammed and Arias, 2016).

Fish are used to normalize the health of aquatic system. African catfish, Clarias gariepinus (C. gariepinus) was selected for the present study for its resistance to stress and high growth rate (Rad et al., 2003; El Naggar et al., 2006; Amisah et al., 2009). It is used in research as an excellent model for toxicological studies (Mekkawy et al., 2011; Hamed, 2016; Sayed and Hamed, 2017).

Hence, this study was designed to: a) Evaluate the effect of Ag-NPs on liver enzymes, oxidant defense mechanism in the liver of African catfish and the histological changes in liver tissues of exposed fish. b) Investigate the protective role of Nigella sativa (NS) against the toxic effects of AgNPs.

\section{MATERIALS AND METHODS}

\section{Chemicals}

Silver nitrate was purchased from Chemajet trade Co., Cairo, Egypt. Stock solutions of silver nanoparticles (AgNPs) at the concentration $(50 \mathrm{mg} / \mathrm{L})$ was prepared according to Ghosh et al., (2012). Nigella sativa was purchased from Local market in Cairo, Egypt.

The kits for liver function (ALP, ALT, and AST),and antioxidant kits (LPO, SOD, CAT, TAC, and GSH) were bought from Biodiagnostic Trade Co., Dokki, Egypt.

\section{Fish rearing}

African catfish, Clarias gariepinus, body length $(31.5 \pm 2.0 \mathrm{~cm})$ and body weight $(200 \pm 50 \mathrm{~g})$, were collected from Abbassa fish farm, Abbassa, Abo-Hammad, Sharqia governorate, Egypt. Fish were treated with potassium permanganate solution $(0.5 \% \mathrm{~W} / \mathrm{V})$ for a minute to abolish any adherents. African catfish were distributed in glass aquaria containing dechlorinated tap for acclimatization for two weeks prior the experiment. water ( $\mathrm{pH} 7.5 \pm .03$ ), total alkalinity $120 \mathrm{mg} / \mathrm{L}$ as $\mathrm{CaCO}_{3}$, total hardness $150 \mathrm{mg} / \mathrm{L}$ as $\mathrm{CaCO}_{3}$, dissolved oxygen $6.3 \pm 0.5 \mathrm{mg} / \mathrm{L}$ and photoperiod 12:12 light: dark. Fish were fed on diet containing $32 \%$ protein. Water in aquaria were changed every 2 days to remove metabolic wastes. 


\section{Experimental design}

African catfish, C. gariepinus were divided into four groups with three replicates, each group contained 15 fish and fed on free basal diet containing 32\% protein for 30 days. Fish were supplied with air using aquarium air pumps.

Group 1: Fish served as control group and fed on free basal diet for 30 days.

Group 2: Fish fed on 3\% Nigella sativa (NS) of basal diet for 30 days.

Group 3: Fish exposed to $50 \mathrm{mg} / \mathrm{L}$ AgNPs for 30 days.

Group 4: Fish exposed to $50 \mathrm{mg} / \mathrm{L}$ AgNPs and fed on $3 \%(N S)$ of basal diet for 30 days.

\section{Clinical investigation}

Behavioral abnormalities, mortality of fish and post-mortem lesions were observed according to Amlacher (1970).

\section{Biochemical analysis}

After the experiment, 10 fish from each group were anaesthetized with $0.02 \%$ benzocaine. Blood samples were collected in clean centrifuge tubes from the caudal veins, allowed to clot, and then centrifuged at $3000 \times \mathrm{g}$ at $4{ }^{\circ} \mathrm{C}$ for $15 \mathrm{~min}$. Serum ALP was determined according to the method described by Tietz et al., (1983). Serum AST and ALT were estimated according to the method described by Reitman and Frankel (1957).

\section{Hepatic lipid peroxidation (LPO) and oxidative stress biomarkers}

Samples of livers tissues were homogenized in cold phosphate buffered saline (0.1M,pH7.4) using a Potter-Elvejhem glass/Teflon homogenizer,then centrifuged. Supernatants were stored at $-20{ }^{\circ} \mathrm{C}$ until analysis. Lipid peroxidation (LPO) levels were detected according to Mihara and Uchiyama (1978). Superoxide dismutase (SOD), catalase (CAT) , Reduced glutathione (GSH), and total antioxidant capacity (TAC) activities were estimated according to Nishikimi et al., (1972); Aebi (1984) ; Beutler et al., (1963); and Koracevic et al., (2001), respectively.

\section{Histopathological studies}

For histological examination, fish were sacrificed by decapitation. Liver tissues were immediately dissected out, fixed in $10 \%$ neutral buffer formalin, sectioned at $4-\mu \mathrm{m}$ thickness, and stained with haematoxylin-eosin (Roberts, 2001).

\section{Statistical analysis}

The data were presented as mean \pm SE. Data were subjected to one-way ANOVA to 
evaluate effects of AgNPs toxicity and feding catfish on (NS) followed by Tukey's post hoc test to compare between groups, $\mathrm{P}<0.05$ was considered statistically significant. All the data analyses were done using SPSS program version 20.

\section{RESULTS}

\section{Behavioral investigation}

Catfish of group (1) fed on basal diet and group (2) fed on 3\% NS of diet exhibited normal behavior and movement. However, catfish exposed to $50 \mathrm{mg} / \mathrm{L}$ AgNPs showed irregular swimming movements, less activity, staying at a certain location for a long time, moving towards the air pumps, and fading of skin was also observed. Additionally, Dietary NS reduced the abnormal behavior of AgNPs - intoxicated catfish .

\section{Biochemical analysis}

The results of serum levels of ALP, ALT, and AST exhibited marked increments in group (3) exposed to $50 \mathrm{mg} / \mathrm{L}$. of AgNPs compared to the control fish (group 1) as shown in table (1). However, feding group (4) exposed to AgNPs on 3\% (NS) decreased these levels near to the levels of the control catfish.

Table (1): Changes in the blood liver enzymes (Mean \pm SE.) of the African catfish, $C$. gariepinus exposed to $50 \mathrm{mg} / \mathrm{L} \mathrm{AgNPs}$ and fed on $3 \% \mathrm{NS}$ for 30 days.

\begin{tabular}{|l|c|c|c|c|}
\hline \multicolumn{1}{c|}{ Groups } & Group 1 & Group 2 & Group 3 & Group 4 \\
\hline Parameters & $23.21 \pm 1.25^{\mathrm{b}}$ & $28.44 \pm 5.64^{\mathrm{b}}$ & $48.22^{\mathrm{a}} \pm 2.89^{\mathrm{a}}$ & $24.31 \pm 3.41^{\mathrm{b}}$ \\
\hline ALT $\mu / 1$ & $30.37 \pm 0.68^{\mathrm{b}}$ & $28.57 \pm 0.70^{\mathrm{b}}$ & $76.67 \pm 10.41^{\mathrm{a}}$ & $38.50 \pm 3.75^{\mathrm{b}}$ \\
\hline AST $\mu / 1$ & $124.04 \pm 20.99^{\mathrm{b}}$ & $103.85 \pm 6.11^{\mathrm{c}}$ & $155.07^{\mathrm{a}} \pm 3.71^{\mathrm{a}}$ & $126.44 \pm 21.88^{\mathrm{b}}$ \\
\hline
\end{tabular}

Means with different superscript letters in the same row for each parameter are different $(\mathrm{P}<0.05)$.

\section{Hepatic lipid peroxidation (LPO) and oxidative stress biomarkers}

The concentration of LPO and the levels of the antioxidant enzymes (SOD, CAT, TAC, and GSH) of the hepatic tissues of catfish exposed to $50 \mathrm{mg} / \mathrm{L} \mathrm{Ag-NPs}$ for 30 days were significantly increased as shown in table (2). Interestingly, catfish exposed to $50 \mathrm{mg} / \mathrm{L} \mathrm{Ag-NPs}$ and fed on 3\% NS (group 4) exhibited marked reductions in the level of hepatic LPO and the activities of antioxidant enzymes (SOD, CAT, TAC, and GSH) (Table2). 
Table (2): Changes in liver antioxidant biomarkers (Mean \pm SE.) of African catfish, $C$. gariepinus exposed to 50mg/L AgNPs and fed on 3\% NS for 30 days.

\begin{tabular}{|l|l|l|l|l|}
\hline \multicolumn{1}{|c|}{ Groups } & \multicolumn{1}{c|}{ Group1 } & \multicolumn{1}{c|}{ Group2 } & Group3 & Group4 \\
Parameters & & & & \\
\hline LPO nmol/g & $16.26 \pm 0.72^{\mathrm{d}}$ & $42.54 \pm 1.98^{\mathrm{c}}$ & $86.67 \pm 2.13^{\mathrm{a}}$ & $63.31 \pm 1.09^{\mathrm{b}}$ \\
\hline GSH nmol/mg & $15.48 \pm 0.82^{\mathrm{c}}$ & $17.96 \pm 1.06^{\mathrm{ab}}$ & $18.77 \pm 0.62^{\mathrm{a}}$ & $20.54 \pm 1.03^{\mathrm{a}}$ \\
\hline CAT $\mu \mathrm{g} / \mathrm{mg}$ & $7.73 \pm 0.63^{\mathrm{c}}$ & $17.10 \pm 0.40^{\mathrm{b}}$ & $37.50 \pm 2.85^{\mathrm{b}}$ & $22.40 \pm 1.42^{\mathrm{b}}$ \\
\hline SOD $\mu \mathrm{g} / \mathrm{mg}$ & $1.34 \pm 0.19^{\mathrm{c}}$ & $4.73 \pm 0.23^{\mathrm{a}}$ & $5.02 \pm 0.45^{\mathrm{a}}$ & $3.08 \pm 0.09^{\mathrm{b}}$ \\
\hline TAC $\mu \mathrm{mol} / \mathrm{mg}$ & $1.22 \pm 0.07^{\mathrm{b}}$ & $2.80 \pm 0.05^{\mathrm{a}}$ & $3.22 \pm 0.38^{\mathrm{a}}$ & $2.48 \pm 0.24^{\mathrm{a}}$ \\
\hline
\end{tabular}

Means with different superecript letters in the same row for each parameter are different $(\mathrm{P}<0.05)$.

\section{Histopathological changes in liver tissues}

The liver tissue slides of Arican catfish in group (1): the control group and group (2): negative control fed on 3\% NS exhibited normal structure of hepatic tissues (Figs. A\&B). However, Liver tissues of catfish exposed to $50 \mathrm{mg} / \mathrm{L} \mathrm{AgNPs} \mathrm{in} \mathrm{group} \mathrm{(3)} \mathrm{for} 30$ days, showed hepatocytes with marked hydropic degeneration, focus of spotty necrosis, a single portal tract with inflammatory cellular infiltrate, and mild fibrosis (Fig. C). Conversely, catfish exposed to $50 \mathrm{mg} / \mathrm{L}$ AgNPs and fed on 3\% NS for 30 days of (group 4) exhibited single portal tract in hepatic tissue with mild inflammatory cellular infiltrate and no fibrosis. No interface hepatitis; No, steatosis, cholestasis or dysplasia were observed (Fig. D). 

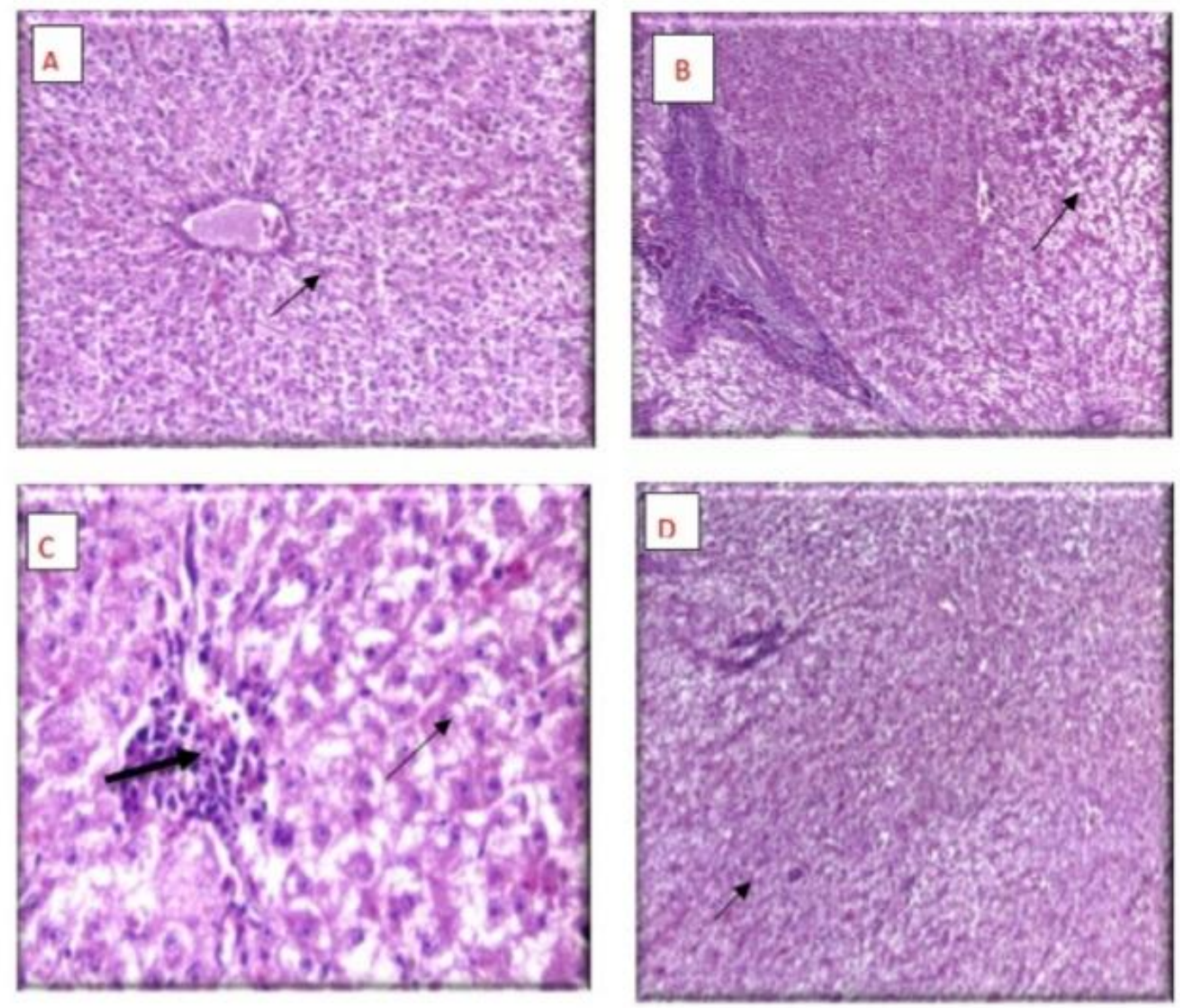

Fig. A: Section in liver tissue of control catfish (group 1), showing normal hepatocytes (thin arrow) with preserved architecture. (H\&E, 400x). Fig. B: Section in liver tissue of catfish fed on $3 \%$ NS of basal diet (group 2), showing normal hepatocytes (thin arrow) (H\&E, 200x). Fig. C: Section in liver tissue of catfish in group (3), exposed to $50 \mathrm{mg} / \mathrm{L}$ AgNPs for 30 days, showing hepatocytes (thin arrow) with mild hydropic degeneration, single portal tract with mild infiltration of inflammatory cells (thick arrow) and focal interface hepatitis (H\&E, 400x). Fig. D: Section in liver tissue of catfish exposed to 50 $\mathrm{mg} / \mathrm{L}$ AgNPs and fed on 3\% NS for 30 days (group 4), showing hepatocytes with no hydropic degeneration. A single portal tract was noticed showing mild infiltration of inflammatory cells (thin arrow) and no fibrosis. No interface hepatitis, No steatosis, cholestasis or dysplasia were observed. (H\&E, 200x).

\section{DISCUSSION}

AgNPs have been used in agricultural crop protection for several years and are found in rivers and ponds, where they are toxic to aquatic organisms including fish. The behavioral alterations in catfish exposed to AgNPs were manifested by loss of equilibrium and abnormal swimming. The abnormal behavior in exposedcatfish may be attributed to the accumulation of acetylcholine at synaptic junctions causing lack in 
muscular coordination of catfish (Prasanth et al., 2005; Hussein et al., 2021). Our results are supported with Bakhshwan et al., (2009); Marzouk et al., (2012); Mekkawy et al., (2013); Campos- Garcia et al., (2016). Co-supplementation with NS declined accumulation of acetylcholine indicating its potential role in muscular coordination.

Assessment of ALP, ALT and AST levels in serum are perfect indicators for diagnosis of liver damage in animals exposed toxic nanoparticles (Samipillai and Jagadeesan, 2005). Levels of ALP, ALT, and AST of catfish exposed to Ag-NPs increased significantly after 30 days of exposure compared with the control catfish. Kumari et al., (2011) and Atli et al., (2015) explained the increase of these enzymes into the bloodstream due to a damage occurred in the hepatic tissues. These results may be due to the accumulation of AgNPs in liver tissues of catfish. The results are in accordance with Hamed and Abdel -Tawwab, (2017); Hamed and Osman, (2017); Abdel Tawwab and Hamed, (2020); Naguib et al., (2020); Hamed et al., (2021); Hussein et al., (2021). However, catfish in group (4) exposed to $50 \mathrm{mg} / \mathrm{L}$ AgNPs and fed on $3 \%$ NS showed marked decrease in serum levels of liver enzymes. Hamed and Abdel Tawwab, (2021) demonstrated that levels of AST, and ALT of Nile tilapia exposed to AgNPs and fed on diets supplemented with pomegranate (Punica granatum) peel reduced significantly after 6 weeks of exposure.

Lipid peroxidation (LPO) is the main contributor to the loss of tissues function under oxidative stress (Huang et al., 2003). The current study revealed a significant increase in LPO levels of hepatic tissues of Ag-NPs - intoxicated catfish (group 3) compared with the control fish (group 1). Similarly, Abdel El-Atti et al., (2020); Hamed and Abdel- Tawwab, (2021) recorded a marked increase in LPO level of crayfish and Nile tilapia exposed to AgNPs, respectively. The increase in LPO level may be due to the elevation in free radicals and overproduction of ROS due to oxidative stress. The responses of LPO may different with time and concentration of toxicants (Ruas et al., 2008). On the other hand, feeding catfish in group (4) on $3 \% N S$ in combination with AgNPs toxicity for 30 days exhibited a marked reduction in the level of hepatic LPO. In other investigations, Sayed and Hamed, (2017); Hamed and El- Sayed, (2019) reported that levels of LPO significantly decreased in liver tissues of 4-nonylphenol-intoxicated catfish treated with Cydonia oblonga and pendimethlin-intoxicated tilapia fish treated with dietary Moringa oleifera.

Furthermore, total antioxidant capacity (TAC) enzyme was increased significantly in liver tissues of African catfish exposed to AgNPs (group 3). The results are supported with the findings of Yonar and Sakin, (2011); Yonar (2012). Additionally, treatment of catfish in group (4) with 3\% NS reduced the hepatic TAC level. The decline in TAC level in the liver of AgNPs-exposed fish fed dietary with $N S$ demonstrates that $N S$ has antioxidant effect aganist AgNPs. 
Reduced glutathione (GSH) plays a vital role in preventing the oxidative damage and maintaining cellular redox status (Dickinson and forman, 2002). Also, superoxide dismutase (SOD), and catalase (CAT) are used as biomarkers of oxidative stress in fishes and considered as the first line of defense against oxidative stress and help in the elimination of hydrogen peroxide (Kadry et al., 2012; Abdel -Tawwab and Wafeek, 2017). The results of this investigation showed marked increments in hepatic GSH , SOD, and CAT levels of catfish exposed to $50 \mathrm{mg} / \mathrm{L}$ AgNPs for 30 days compared with the control fish. The presence of transition metals and the metallic nature of nanoparticles induce the production of ROS, causing oxidative stress (MacNee and Donaldson, 2003; Rajkumar et al., 2016). Likewise, Kadry et al., (2012) recorded marked elevation in the activity of hepatic SOD, and CAT enzymes of African catfish exposed to atrazine. However, our results demonstrated that feeding catfish in group (4) on NS enriched diet significantly attenuated the increase in GSH, SOD, and CAT levels in the hepatic tissues as a response to AgNPs exposure (Table 2), demonstrating that $N S$ has a hepatoprotective effect against AgNPs -induced oxidative stress.

Liver is a vital organ in detoxification, active metabolism and is sensitive to xenobiotics (Brusle and Anadon, 1996). Histopathology of liver in fishes is an indicator of chemical toxicity and a good tool to show the effect of exposure of aquatic animals to toxicants found in the aquatic environment (Fernandes et al., 2008). In the present investigation, the effects of AgNPs were observed in the liver tissue of catfish. These findings are consistent with Rajkumar et al., (2016) ; Ostaszewska et al., (2018); and Naguib et al., (2020) who observed proliferation of hepatocytes, cytoplasmic vaculation, infiltrations of inflammatory cells, hepatic necrosis, and dilation in the blood vessel of Labio rohita, rainbow trout, Oncorhynchus mykiss and African catfish, C. gariepinus exposed to AgNPs, respectively. These alterations may be attributed to the toxic effect of nanoparticles on liver cells. On other side, liver tissues of catfish (group 4) treated with $3 \% N S$ along with exposure to Ag-NPs showed mild infiltration of inflammatory cells and a significant reduction in the histological changes of liver (Fig. D). Hence, dietary $N S$ plays a modulatory role in preventing and/or repairing the histopathological abnormalities of liver induced by AgNPs.

\section{CONCLUSION}

The results of this study confirmed toxic effects of AgNPs on the behavioral, biochemical changes, and antioxidant biomarkers. In addition, the histopathological alterations in hepatic tissues of African catfish, C. gariepinus were recorded. Additionally, feeding catfish exposed to AgNPs on NS could reduce the destructive impacts of AgNPs. 


\section{REFERENCES}

Abarghoei, S.; Hedayati, A.; Ghorbani, R.; Miandareh, H.K. and Bagheri, T. (2016). Histopathological effects of waterborne silver nanoparticles and silver salt on the gills and liver of goldfish, Carassius auratus. Int. J. Environ. Sci. Technol., 13(7):1753-1760.

Abd El-Atti, M.; Desouky, M.; Mohamadien, A. and Said, R. (2020). Sub-lethal toxicity of silver nanoparticles on crayfish, procambarus clarkii: oxidative stress, DNA damage, and histopathological alterations. Arct. J., 73(3).

Abdel Tawwab, M. and Hamed HS. (2020). Antagonistic effect of dietary guava (Psidium guajava) leaves extract on growth hemato-biochemical, and immunity response of cypermethrin- intoxicated Nile tilapia, Oreochromis niloticus, fingerlings. Aquaculture, 529: 735668.

Abdel-Tawwab, M. and Wafeek, M. (2017). Fluctuations in water temperature affected waterborne cadmium toxicity: hematology, anaerobic glucose pathway, and oxidative stress status of Nile tilapia, Oreochromis niloticus (L.). Aquaculture, 477:106-111.

Adam, G.O.; Rahman, M.M.; Lee, S.J.; Kim, G.B.; Kang, H.S.; Kim, J.S. and Kim, S.J. (2016). Hepatoprotective effect of Nigella sativa seed extract against acetaminophen induced oxidative stress. Asian Pac. J. Trop. Med., 9:221-227.

Aebi, H. (1984). Catalase in vitro. Methods Enzymol., 105:121-126.

Alti, G.; Ariyurek, S.Y.; Kanak, E.G. and Canli, M. (2015). Alterations in the serum biomarkers belonging to different metabolic system of fish (Oreochromis niloticus) after $\mathrm{Cd}$ and $\mathrm{Pb}$ exposure. Environ. Toxicol. Pharmacol., 40(2): 508515 .

Amin, B. and Hosseinzadeh, H. (2016). Black cumin (Nigella sativa) and its active constituent, thymoquinone: an overview on the analgesic and anti-inflammatory effects. Planta. Med., 82:8-16.

Amisah, S.; Oteng, A.M. and Ofori, J. K. (2009). Growth performance of the African catfish (Clarias gariepinus) fed varying inclusion levels of Leucanena leaf meal. J. Appl. Sci. Environ. Manag., 13(1): 21-26. 
Amlacher, E. (1970). «Text book of fish diseases» PP: 135-137. T.E.S.Publication, Jersy, USA.

Arora, S.; Jain, J.; Rajwade, J. and Paknikar, K. (2009). Interactions of silver nanoparticles with primary mouse fibroblasts and liver cells. Toxicol. Appl. Pharmacol., 236 (3): 310-318.

Bakhshwan, S.A.; Marzouk, M.S.; Hanna, M.I. and Hamed, H.S. (2009). Some investigation on the clinical and biochemical alteration associated with diazinon toxicity in Clarias gariepinus. Egypt. J. Aquat. Biol. Fish. 13:173-197.

Beutler, E.; Duron, O. and Kelly, B.M. (1963). Improve method for the determination of blood glutathione. J. Lab. Clin. Med., 61:882-888.

Blaser, S.A.; Scheringer, M.; Macleod, M. and Hungerbühler, K. (2008). Estimation of cumulative aquatic exposure and risk due to silver: contribution of nanofunctionalized plastic and textiles. Sci. Total. Environ., 390: 396-409.

Brusle, J. and Anadon, G.G.I. (1996). The structure and function of fish liver, Fish Morphology, Horizon of New Research vol. 128, Science Publisher Inc., New Hampshire.

Campos-Garcia, J.; Martinez, D.S.T.; Rezende, K.F.O.; da silva, J.R.M.C.; Alves, O.L. and Barbieri, E. (2016). Histopathological alteration in the gill of Nile tilapia exposed to carbfuran and multiwalled carbon nanotubes. Ecotoxicol. Environ. Saf., 133:481-488.

Dickinson, D.A. and Forman, H.J. (2002). cellular glutathione and thiols metabolism. Biochem. Pharmacol., 64:1019-1026.

El Naggar, G.O.; John, G.; Rezk, M.A.; Elwan, W. and Yehia, M., (2006). Effect of varying density and water level on the spawning response of African catfish Clarias gariepinus: implications for seed production. Aquaculture, 26(3): 904907. 
Fabrega, J.; Luoma, S.N.; Tyler, C.R.; Galloway, T.S. and Lead, J.R. (2011).Silver nanoparticles: Behaviour and effects in the aquatic environment. Environ. Int., 37(2): 517-531.

Fernandes, C.; Fontaĺnhas-Fernandes, A.; Rocha, E. and Salgado, M.A. (2008). Monitoring pollution in Esmoriz-paramos lagoon, Portugal: liver histological and biochemical effect in Liza saliens. Environ. Monit. Assess.,145(13):315-322.

Ghosh, M.; Manivannan, J.; Sinha, S.; Chakraborty, A. and Mallick, S.K. (2012). In vitro and in vivo genotoxicty of silver nanoparticles. Mut. Res. Gen. Toxicol. Environ. Mutagen., 749(1-2):60-69.

Hamed, H.S. (2016). Ameliorative effects of Spirulina platensis on deltamethrin -

induced biochemical alterations and oxidative stress in the African catfish:

Clarias gariepinus. OJMS, 6:1-10.

Hamed, H.S. and Abdel-Tawwab, M. (2017). Ameliorative effect of propolis supplementation on alleviating Bisphenol-A toxicity: Growth performance, biochemical variables, and oxidative stress biomarkers of Nile tilapia, Oreochromis niloticus (L.) fingerlings, Comp. Biochem. Physiol. Part C, Toxicol. Pharmacol., 202: 63-69.

Hamed, H.S. and Abdel-Tawwab, M. (2021) Dietary pomegranate (Punica granatum) peel mitigated the adverse effects of silver nanoparticles on the performance, haemato-biochemical, antioxidant, and immune responses of Nile tilapia fingerlings, Aquaculture, 540: 736742 .

Hamed, H.S. and Osman, A.M. (2017). Modulatory effect of lycopene against carbofuran toxicity in African catfish, Clarias gariepinus. Fish Physiol. Bichem., 43(6): 1721-1731.

Hamed, H.S. and El-sayed, Y.S. (2019). Antioxidant activities of Moringa oleifera leaf extract against pendimethalin-induced oxidative stress and genotoxicity in Nile tilapia, Oreochromis niloticus (L.) Fish. Physiol. Biochem., 45(1): 71-82.

Hamed, H.S.; Ismal, S.M. and Faggio, C. (2021). Effect of allicin on antioxidant defense system, and immune response after carbofuran exposure in nile tilapia, Oreochromis niloticus. Comp. Biochem Physiol part (C) Toxicol. Pharmacol., 240: 108919. 
Huang, C.H.; Chang, R.J.; Huang, S.L. and Chen, W. (2003). Dietary vitamin E supplementation affects tissue lipid peroxidation of hybrid tilapia, Oreochromis niloticus x O. aureus. Comp. Biochem. Physiol. Part (B) Biochem. Mol. Biol.,134(2): 265-70.

Hussein, N.M.; Saeed, R.M.A.; Shaheen, A.A. and Hamed, H.S. (2021). Ameliorative role of chitosan nanoparticles against bisphenol-A induced behavioral, biochemical changes and nephrotoxicity in the African catfish, Clarias gariepinus. Egypt. J. Aquat. Biol. Fish., 25(1): 493-510.

Ijaz, H.; Tulain, U.R.; Qureshi, J.; Danish, Z.; Musayab, S.; Akhtar, M.F.; Saleem, A.; Khan, k.k.; Zaman, M.; Waheed, I.; Khan, I. and Abdel-Daim, M. (2017). Review: Nigella sativa (Prophetic medicine): a review. Pak. J. Pharm. Sci., 30:229-234.

Kadry, S.M.; Marzouk, M.S.; Amer, A.M.; Hanna, M.I.; Azmy, A.H. and Hamed, H.S. (2012) Vitamin E as antioxidant in femaleAfrican catfish (Clarias gariepinus) exposed to chronic toxicity of atrazine. Egypt. J. Aquat. Biol. Fish., 16:83-98

Koracevic, D.; Koracevic, G.; Djordjevic, V.; Andrejevic, S. and Cosic, V. (2001). Method for the measurement of antioxidant activity in human fluids. J. Clin. Pathol., 54:356-361.

Kumari, K.; Nitish, R. and Sinha, R.C. (2011). Multiple biomarker response in the fish, Labeo rohita due to hexavalent chromium. Proceedings of the $2^{\text {nd }}$ International Conference on Biotechnology and food science. IPCBEE vol.7 IACSIT Press, Singapore.

Mac Nee, W. and Donaldson, K. (2003). Mechanism of lung injury caused by $\mathrm{PM}_{10}$ and ultrafine particles with special reference to COPD. Eur. Respir. J., 21(40): 47-51.

Marzouk, M.S.; Kadry, S.M.; Amer, A.M.; Hanna, M.I.; Azmy, A.H. and Hamed, H.S. (2012). Effect of atrazine exposure on behavioral, haematological and biochemical aspects of female African catfish (Clarias gariepinus). J. Sci. Res., 9:290-299.

Mekkawy, I.A.; Mahmoud, U.M. and Mahmoud, R.H. (2013). Protective effect of tomato paste and vitamin $\mathrm{E}$ on atrazine- induced hematological and biochemical characteristics of Clarias gariepinus (Burchell, 1822). GARJEST, 2: 11-21.

Mekkawy, I.A.; Mahmoud, U.M.; Wassif, E.T. and Naguib, M. (2011). Effect of cadmium on som haematological and biochemical characteristics of Oreochromis 
niloticus (Linnaeus, 1758) diatry supplemented with tomato paste and vitamin E. Fish physiol. Biochem., 37:71-84.

Mihara, M. and Uchiyama, M. (1978). Determination of malonaldehyde precursor in tissue by thiobarbituric acid test. Anal. Biochem., 86: 271-278.

Mohamed, H.H. and Arias, C.R. (2016). Proactive efficacy of Nigella sativa seeds and oil against columnaris disease in fishes. J. Fish Dis., 39: 693-703.

Naguib, M.; Mahmoud, U.M.; Mekkawy, I.A. and Sayed A.E.H. (2020). Hepatotoxic effects of silver nanoparticles on Clarias gariepinus; Biochemical, histopathological, and histochemical studies. Toxicol. Rep., 7: 133-141.

Nishikimi, M.; Appaji, N. and Yagi, K. (1972). The occurrence of superoxide anion in the reaction of reduced phenazine methosulfate and molecular oxygen. Biochem. Biophys. Res. Commun., 46: 849-854.

Ostaszewska, T.; Śliwiński, J.; Kamaszewski, M.; Sysa, P. and Chojnacki, M. (2018). Cytotoxicity of silver and copper nanoparticles on rainbow trout (Oncorhynchus mykiss) hepatocytes. Environ. Sci. Pollut. Res. Int., 25(1): 908-915.

Prasanth, M.S.; David, M. and Mathed, S.G. (2005). Behavioral changes in freshwater fish Cirrhinus mrigala Hamilton exposed to cypermethrin. J. Ecotoxicol. Environ. Monit., 26:141-144.

Rad, F.; Kurt, G.I. and Bozaoulu, A.S. (2003). Effect of spatially localized and dispersed patterns of feed distribution on the growth, size dispersion and feed conversion ratio of the African catfish (Clarias gariepinus ). Turk. J. Anim. Sci., 28:851856.

Rajkumar, K.S.; Kanipandian, N. and Thirumurugan, R. (2016).Toxicity assessment on haemotology, biochemical and histopathological alterations of silver nanoparticles-exposed freshwater fish Labeo rohita, Appl. Nanosci., 6: 19-29.

Reitman, S. and Frankel, S. (1957). A colorimetric method for the determination of serum glutamic oxalacetic and glutamic pyruvic transaminases. Am. J. Clin. Pathol., 28:56-63.

Roberts, R.J. (2001). Fish pathology. $3^{\text {rd }}$ ed., Bailliere tindall, London, England.

Ruas, C.B.G.; Carvalho, C.D.S.; de Araújo, H.S.S.; Espíndola, E.L.G. and Fernandes, M.N. (2008). Oxidative stress biomarkers of exposure in the blood of cichlid species from a metal-contaminated river. Ecotoxicol. Environ. Saf., 71 (1): 86-93. 
Samipillai, S. and Jagadeesan, G. (2005). Influence of taurine on phosphatases activity in selected tissues of mercuric chloride intoxicated mice. J. Exp. Zool., 8: 295300 .

Sayed, A.E.H. and Hamed, H.S. (2017). Induction of apoptosis and DNA damage by 4nonylphenol in African catfish (Clarias gariepinus) and the antioxidant role of Cydonia Oblonga. Ecotoxicol..Environ.Saf.,139: 97-101.

Shahid, F.; Farooqui, Z.; Rizwan, S.; Abidi, S.; Parwez, I. and Khan, F. (2017). Oral administration of Nigella sativa oil ameliorates the effect of cisplatin on brush border membrane enzymes, carbohydrate metabolism and antioxidant system in rat intestine. Exp. Toxicol. Pathol., 69: 299-306.

Tietz, N.W. (1995). Clinical Guide to Laboratory tests. $3^{\text {rd }}$ ed. Philadelphia. WB. Saunders, 268-273.

Wijnhoven, S.W.P.; Peijnenburg, W.J.G.M.; Herberts, C.A.; Hagens, W.I.; Oomen, A.G.; Heugens, E.H.W.; Roszek, B.; Bisschops, J.; Gosens, I.; De Meent, D.V.; Dekkers, S.; De Jong, W.H.; van Zijverden, M.; Adriënne, J.A.M.; Sips, A.J.A.M. and Geertsma, R.E. (2009). Nano-silver - a review of available data and knowledge gaps in human and environmental risk assessment. Nanotoxicology, 3(2): 109-138.

Yonar, M.E. (2012). The effect of lycopene on oxytetracycline-induced oxidative stress and immunosuppression in rainbow trout (Oncorhynchus mykiss, W.). Fish Shellfish Immunol., 32: 994-1001.

Yonar, M.E. and Sakin, F. (2011). Ameliorative effect of lycopene on antioxidant status in Cyprinus carpio during pyrethroid deltamethrin exposure. Pest. Biochem. Physiol., 99:266-231.

Yue, Y.; Behra, R.; Sigg, L.; Freire, P.F.; Pillai, S. and Schirmer, K. (2015). Toxicity of silver nanoparticles to a fish gill cell line: Role of medium composition. Nanotoxicology, 9(1): 54-63.

Zhou, B.; Nichols, J.; Playle, R.C. and Wood, C.M. (2005). An in vitro biotic ligand model (BLM) for silver binding to cultured gill epithelia of freshwater rainbow trout (Oncorhynchus mykiss). Toxicol. Appl. Pharmacol., 202: 25-37. 